\title{
HUBUNGAN DUKUNGAN KELUARGA DENGAN TINGKAT ANSIETAS PASIEN PRE OPERASI MAYOR
}

\author{
Reza Maghfirotun Nisa ${ }^{1}$, Livana $\mathbf{P H}^{\mathbf{1}}$, Triana Arisdiani ${ }^{1}$ \\ ${ }^{1}$ Program Ners Sekolah Tinggi Ilmu Kesehatan Kendal \\ livana.ph@gmail.com
}

\begin{abstract}
ABSTRAK
Pasien yang menjalani operasi akan muncul perasaan ansietas seperti ketakutan atau perasaan tidak tenang, marah dan kekhawatiran. Ansietas tersebut dapat dilihat dari dukungan keluarga salah satu anggota keluarga sangat berperan aktif dalam mengurangi tingkat ansietas. Penelitian ini betujuan untuk mengetahui hubungan karakateristik dan dukungan keluarga dengan tingkat ansietas pasien pre operasi mayor. Penelitian ini menggunakan metode kuantitatif melalui pendekatan cross sectional, pengumpulan data menggunakan kuesioner dengan 16 pertanyaan tentang dukungan keluarga yang telah dilakukan uji validitas dengan nilai $\mathrm{r}$ variabel 0,90 , tekhnik sampel menggunakan purposive sampling dengan jumlah sampel167 responden. Penelitian menunjukkan bahwa ada hubungan yang signifikan antara karakteristik dukungan keluarga dengan tingkat ansietas pasien pre operasi mayor dengan nilai $p$ value $<0,005$. Keluarga disarankan dapat melakukan dukungan terhadap anggota keluarga yang akan dilakukan tindakan operasi.
\end{abstract}

Kata kunci: Dukungan Keluarga, Ansietas Pre-operasi

\section{THE RELATIONSHIP KARAKATERISTIK AND FAMILY SUPPORT WITH ANXIETY LEVELS OF PATIENTS PRE MAJOR SURGERY}

\begin{abstract}
Patients undergoing surgery are afraid of anesthesia, fear of pain and death about ignorance or deformity or other threats to the body image resulting in anxiety, the anxiety can be seen from several characteristics of age, sex, education level, and occupation, so family support of one family member plays an active role in reducing the level of anxiety. This study aims to determine the relationship karakateristik and family support with anxiety levels of patients pre major surgery in RSUD Dr. $H$. Soewondo Kendal. This research uses quantitative method through cross sectional approach, data collecting using questionnaires with 16 question about family support which has been done validity test with $r$ value of variable 0,90, the sample technique used purposive sampling with 167 respondents. The results showed that there was a significant relationship between the characteristics of family support with anxiety levels of patients pre major surgery with $p$ value $<0.005$. Families are advised to support family members for surgery.
\end{abstract}

Keywords: Family Support, ansietas pre-operation

\section{PENDAHULUAN}

Operasi adalah semua tindakan pengobatan yang menggunakan cara invasif dengan membuka atau menampilkan bagian tubuh, dan pada umumnya dilakukan dengan membuat sayatan, pada bagian tubuh yang akan ditangani, lalu dilakukan tindakan perbaikan dan diakhiri dengan penutupan dan penjahitan luka (Sjamsu hidajat, 2008). Pandangan setiap orang dalam menghadapi pre operasi berbeda, sehingga respon pun berbeda. Setiap menghadapi pre operasi selalu menimbulkan ansietas. Ansietas menurut Kusumawati \& Hartono, (2011) adalah pengalaman subjektif dari seseorang yang membuat tidak nyaman selalu berkaitan dengan perasaan yang tidak berdaya dapat memberikan dampak yang mempengaruhi fungsi fisiologis dan psikologis.

Dampak fungsi fisiologis yang ditandai dengan adanya perubahan-perubahan fisik seperti meningkatkan frekuensi nadi dan pernafasan, gerakan-gerakan tangan yang tidak terkontrol, telapak tangan lembab, gelisah, menanyakan pertanyaan yang sama berulang kali, sulit tidur, dan sering BAK (buang air kencing) (Smeltzer \& Bare, 2013). Menurut Hawari (2011) seseorang yang mengalami ansietas menimbulkan dampak psikologis antara lain: 
khawatir, takut akan kematian, mudah tersinggung, gelisah mudah terkejut, takut pada keramaian, oleh karena itu diperlukan adanya dukungan keluarga. Menurut Ratna (2010) dukungan keluarga merupakan unsur penting dalam perawatan, khususnya pasien yang akan menjalani operasi. Bentuk dukungan ini membuat individu memiliki perasaan nyaman, yakin, diperdulikan, nasihat yang mampu membuat penerima dukungan akan merasa disayang, dihargai, dan dicintai oleh keluarga sehingga individu dapat menghadapi masalah dengan baik.

Berdasarkan hasil penelitian di 56 negara dari 192 negara anggota World Health Organization (WHO) diperkirakan 234,2 juta prosedur operasi dilakukan setiap tahun berpotensi komplikasi dan kematian (Puspita, Armiyati, \& Arif, 2014). tindakan operasi di Indonesia meningkat dari tahun ke tahun dengan jumlah 810.000 orang per tahun Angka perbandingan antara perempuan dengan lakilaki, yaitu perempuan mencapai 50,15\%, sedangkan laki-laki sebanyak 30,5\%, dan operasi anak dibawa umur sekitar 10\% sampai 15\% (Suara Merdeka.Com, 2010). tindakan operasi di provinsi jawa tengah tahun 2009 sebesar 3.884 kasus (36,38\%), dari tahun 2008-2009 kejadian tindakan operasi mengalami kenaikan 89, 95\% (Depkes RI,
2009). Studi pendahuluan yang dilakukan peneliti di Kendal pada tanggal 10 Oktober 2017 didapatkan dari 7 responden yang mengalami pre operasi 4 responden mengalami ansietas sedang, 3 responden mengalami ansietas ringan dengan menggunakan kuesioner DASS (Depression Anxiety Stress Scales). Berdasarkan latar belakang tersebut peneliti melakukan penelitian yang bertujuan untuk mengetahui mengetahui hubungan dukungan keluarga dengan tingkat ansietas pada pasien pre operasi mayor.

\section{METODE}

Metode yang digunakan adalah metode deskriptif korelasi dengan pendekatan cross sectional. Populasi dalam penelitian ini adalah seluruh pasien yang akan dilakukan operasi mayor di Kendal. Sampel penelitian sebanyak 167 responden. Teknik yang dipilih dengan menggunakan teknik purposive sampling. Alat penelitian ini menggunakan kuesioner yang telah terstruktur. Analisa menggunakan dua analisa yaitu univariat dan bivariat. Analisa univariat menggunakan distribusi frekuensi dan persentase. Analisis bivariat menggunakan uji chi-square.

\section{HASIL}

Hasil penelitian disajikan pada tabel berikut.

Tabel 1.

Karakteristik Menurut Usia Responden Pasien Pre Operasi Mayor $(n=167)$.

\begin{tabular}{ccccc}
\hline Mean & Median & Min & Max & SD \\
\hline 43,78 & 45,00 & 23 & 64 & 10,009 \\
\hline
\end{tabular}

Karakteristik responden berdasarkan usia bahwa rata-rata usia responden adalah 43,78 tahun dengan usia minimal 23 tahun dan usia maksimal 64 tahun.

Tabel 2.

Karakteristik responden, $(\mathrm{n}=167)$.

\begin{tabular}{|c|c|c|}
\hline Variabel & $\mathrm{f}$ & $\%$ \\
\hline laki-laki & 52 & 31,1 \\
\hline Perempuan & 115 & 68,9 \\
\hline perguruan tinggi & 12 & 7,2 \\
\hline D3 & 3 & 1,8 \\
\hline SMA & 27 & 16,2 \\
\hline SMP & 32 & 19,2 \\
\hline SD & 64 & 38,3 \\
\hline Tidak sekolah & 29 & 17,4 \\
\hline perguruan tinggi & 12 & 7,2 \\
\hline D3 & 3 & 1,8 \\
\hline SMA & 27 & 16,2 \\
\hline SMP & 32 & 19,2 \\
\hline SD & 64 & 38,3 \\
\hline Tidak sekolah & 29 & 17,4 \\
\hline
\end{tabular}


Karakteristik responden berdasarkan jenis kelamin yaitu berjenis kelamin perempuan, tingat pendidikan mayoritas berpendidikan
Sekolah Dasar, dan pekerjaan mayoritas berkerja sebagai petani/buruh.

Tabel 3.

Tingkat Ansietas Responden Pasien Pre Operasi Mayorn(n=167).

\begin{tabular}{lcc}
\hline \multicolumn{1}{c}{ Variabel } & $\mathrm{f}$ & $\%$ \\
\hline Ansietas sedang & 112 & 67,1 \\
Ansietas berat & 55 & 32,9 \\
\hline
\end{tabular}

Tingkat ansietas pasien pre operasi mayor di RSUD Dr. H. Soewondo Kendal sebagian besar mengalami ansietas sedang.

Tabel 5.

Dukungan Keluarga Responden Pasien Pre Operasi Mayor(n=167).

\begin{tabular}{|c|c|c|}
\hline Variabel & $\mathrm{f}$ & $\%$ \\
\hline Cukup & 56 & 33,5 \\
\hline Baik & 111 & 66,5 \\
\hline Total & 167 & 100 \\
\hline
\end{tabular}

Dukungan keluarga responden sebagian besar baik.

Tabel 10.

Hubungan Dukungan keluarga pasien dengan tingkat ansietas pada pasien pre operasi mayor, $(n=167)$.

\begin{tabular}{|c|c|c|c|c|c|c|c|}
\hline \multicolumn{8}{|c|}{ HRS_A Tingkat Ansietas } \\
\hline \multirow[t]{2}{*}{ Variabel } & \multicolumn{2}{|c|}{$\begin{array}{c}\text { Ansietas } \\
\text { sedang }\end{array}$} & \multicolumn{2}{|c|}{ Ansietas berat } & \multicolumn{2}{|c|}{ Total } & \multirow[t]{2}{*}{$\begin{array}{c}P \\
\text { Value }\end{array}$} \\
\hline & $f$ & $\%$ & $f$ & $\%$ & $\mathrm{f}$ & $\%$ & \\
\hline Cukup & 3 & 5,4 & 53 & 94,6 & 56 & 33,54 & 0,000 \\
\hline Baik & 109 & 98,2 & 2 & 1,8 & 111 & 66,46 & \\
\hline Total & 112 & 67,1 & 55 & 32,9 & 167 & 100 & \\
\hline
\end{tabular}

Dukungan keluarga sebagian besar memiliki dukungan yang baik dengan tingkat ansietas sedang sebanyak 109 $(98,2 \%)$. Hasil statistik chi-square didapatkan $P$ value $=0,000(\mathrm{a}<0,05)$ sehingga Ho ditolak dan Ha diterima yang artinya terdapat hubungan yang signifikan antara dukungan keluarga dengan tingkat ansietas pasien pre operasi mayor.

\section{PEMBAHASAN}

Hasil penelitian ini menunjukkan sebagian besar dari 167 responden rata-rata berusia 43,78 tahun. Berdasarkan pendapat Hawari, (2013) usia dewasa akan lebih mudah memahami lingkungan disekitarnya termasuk perawatan dan resiko dampak penyakit yang dialami pasien akibat dari pengalaman dan kematangan jiwanya. Hasil penelitian yang didapatkan oleh Supriati (2017) menunjukkan bahwa rata - rata usia pasien adalah 37,89 tahun termasuk kategori dalam usia dewasa awal.

Hasil penelitian menunjukkan bahwa jenis kelamin perempuan yang mengalami ansietas sedang sebanyak $98(85,2 \%)$ dan ansietas berat sebanyak $17(14,8 \%)$. Hal ini sesuai teori Stuart (2013) bahwa wanita lebih mudah mengalami ansietas disebabkan wanita lebih cenderung menggunakan perasaan, sedangkan pria lebih menggunakan logika. Berdasarkan hasil penelitian yang didaptkan oleh Farida dan Virgianti (2015) menunjukkan bahwa pasien pre operasi laparatomi yang sebagian besar berjenis kelamin perempuan karena perempuan merasakan kekhawatiran yang tinggi terhadap operasi yang akan dijalani.

Hasil penelitian menunjukkan bahwa pendidikan SD yang mengalami ansietas 
sedang sebanyak $35(54,7 \%)$ dan ansietas berat sebanyak $29(45,3 \%)$. Hal ini sesuai pendapat dari Notoatmodjo (2012) dan Hawari (2013) bahwa Pendidikan merupakan jenjang yang didapat seseorang didalam suatu lembaga pendidikan, pendidikan seseorang yang rendah akan menyebabkan individu tersebut lebih mudah mengalami ansietas dibanding dengan individu yang berpendidikan lebih tinggi, akan lebih rasional dalam menghadapi masalah dalam kehidupannya. Hasil penelitian yang lakukan oleh Erkilic, et.al (2017) didapatkan sebagian besar berpendidikan rendah karena orang yang berpendidikan rendah akan semakin sulit berpikir secara rasional dalan menguraiakan suatu masalah.

Hasil penelitian menunjukkan bahwa pekerjaan petani/buruh yang mengalami ansietas sedang sebanyak $38(56,7 \%)$ dan ansietas berat sebanyak 29 (43,3\%). Hasil ini sesuai dengan teori Stuart (2013) bahwa seseorang yang memiliki kualitas bekerja yang tidak baik pasien akan memunculkan ansietas yang tinggi. Hasil penelitiann yang didapatkan oleh Dwi dan Suhardi (2014) dapat dilihat dari karakteristik responden berdasarkan pekerjaan sebagai besar bekerja sebagai swasta karena individu berpikir akan mengalami penurunan kualitas dalam bekerja.

Hasil penelitian menunjukkan tingkat ansietas pasien pre operasi mayor sebagian besar mengalami ansietas sedang. ansietas sedang adalah persepsi terhadap lingkungan menurun, individu lebih menfokuskan pada hal penting saat itu dan mengesampingkan hal lain. Sehingga pasien mengalami perhatian yang elektif namun dapat melakukan sesuatu yang terarah (Hawari, 2013). Hasil penelitian Ulfa (2017) didapatkan bahwa mayoritas mengalami ansietas sedang pada pasien pre operasi terancana.

Hasil penelitian menunjukkan bahwa dukungan keluarga pasien yang baik. Hasil penelitian ini sesuai dengan teori Friedman (2010). Berpendapat bahwa dukungan keluarga yaitu sikap, tindakan dan penerimaan keluarga terhadap penderita sakit. Salah satu peran dan fungsi keluarga adalah memberikan fungsi afektif untuk pemenuhan kebutuhan secara psikososial anggota keluarganya dalam memberikan kasih sayang. Hasil penelitian ini sejalan dengan penelitian yang dilakukan oleh Sitepu dan Nasution (2015) diketahui bahwa dukungan keluarga pada pasien pre operasi yang memiliki dukungan yang baik dari pihak keluarganya.

Hasil penelitian yang dilakukan di ruang rawat inap menunjukan bahwa dukungan keluarga pasien baik yang mengalami ansietas sedang sebanyak $106(94,6 \%)$ dan ansietas berat sebanyak $6(5,4 \%)$. Bahwa dukungan keluarga meliputi sikap, tindakan dan penerimaan keluarga terhadap penderita sakit, Salah satu peran dan fungsi keluarga yaitu memberikan fungsi afektif untuk pemenuhan kebutuhan psikososial anggota keluarganya dalam memberikan kasih sayang Friedman (2010). Hasil penelitian ini sejalan dengan penelitian yang dilakukan oleh Romadoni (2016) terdapat hubungan antara dukungan keluarga dengan tingkat ansietas pasien pre operasi mayor disebabkan bahwa dukungan keluarga dari pihak keluarga sangat dibutuhkan terhadap penderita sakit, anggota keluarga sangat penting, sehingga anggota keluarga tersebut meras nyaman dan dicintai apabila dukungan keluarga tersebut tidak adekuat maka merasa diasingkan atau tidak dianggap oleh keluarga, sehingga seseorang akan mudah mengalami ansietas dalam menjalani operasi.

\section{SIMPULAN DAN SARAN}

\section{Simpulan}

1. Karakteristik pasien pre operasi mayor dalam penelitian ini didapatkan bahwa ratarata berusia 44 tahun, sebagian besar responden berjenis kelamin perempuan, tingkat pendidikan sekolah dasar, dan bekerja sebagai petani/buruh.

2. Pasien pre operasi mayor sebagian besar memiliki dukungan keluarga yang baik.

3. Pasien pre operasi mayor sebagian besar mengalami tingkat ansietas sedang. 
4. Ada hubungan antara dukungan keluarga dengan tingkat kecemasan pasien pre operasi mayor $(\rho$ value $<0,05)$.

\section{Saran}

Bagi Peneliti dapat meningkatkan sumber pengetahuan, wawasan mengenai dukungan keluarga dengan tingkat ansietas pasien pre operasi mayor, bagi Institusi pendidikan dapat menerapakan sebagai bahan referensi perpustakaan dan sumber bacaan untuk memperkaya pengetahuan mahasiswa tentang dukungan keluarga dengan tingkat ansietas pasien pre operasi mayor, Bagi Perawat atau tim kesehatan rumah Sakit dapat digunakan dapat menerapakan sebagai edukasi tentang persiapan dan prosedur operasi untuk mengurangi tingkat ansietas pada pasien pre operasi mayor, bagi Peneliti Selanjutnya dapat menerapkan sebagai bahan referensi dan pedoman untuk peneliti selanjutnya untuk melakukan penelitian yang berbeda dengan menggunakan variabel yang berbeda.

\section{DAFTAR PUSTAKA}

Hawari. (2013). Manajemen Stress, Cemas, Dan Depresi. Jakarta: FKUI.

Friedman, MM., Bowden, V.R., \& Jones, E.G. (2010). Buku Ajar Keperawatan Keluarga: Riset, teori, dan praktik, alih bahasa, Akhir Yani S. Hamid dkk; Ed 5. Jakarta : EGC.

Notoatmodjo. (2012). Promosi Kesehatan dan Ilmu Perilaku. Jakarta : Rineka. Cipta.

Romdoni, Siti. (2016). Karakteristik Dan Dukungan Keluarga Dengan Tingkat Kecemasan Pasien Pre Operasi Mayor Di Rumah Sakit Muhammadiyah Palembang. STIKes Muhammadiyah Palembang. Volume 4, Nomor 1, Juni 2016.

Stuart, G. W. (2013). Buku Saku Keperawatan jiwa. Jakarta : EGC.

Depkes RI. (2009). Profil Kesehatan 2008. Jakarta. http://www.depkes.go.id.

Kusumawati F \& Hartono Y. (2011). Buku Ajar Keperawatan Jiwa. Jakarta : EGC.

Muttaqin, Arif dan Kumala Sari. (2009). Asuhan Keperawatan Perioperatif
Konsep, Proses, dan Aplikasi. Jakarta : Salemba Medika.

Ratna, W. (2010). Sosiologi dan antropologi kesehatan. Yogyakarta: Pustaka Rihama.

Sjamsuhidajat R, (2008). Buku Ajar Ilmu Bedah. Edisi 3. Jakarta: EGC.

Smeltzer \& Bare (2013), Buku Ajar Keperawtan Medikal Bedah Bruner \& Suddarth Edisi 8. Jakarta : EGC.

Erkilic E,. Kesimci E,. Soykut C,. Doger C,. Gumus T,. Kanbak O. (2017). Factors associated with preoperative anxiety levels of Turkish surgical patients: from a single center in Ankara. Volume II. No 11. https://doi.org/10.2147/PPA.S12734.

Faridah., Virgianti Nur. (2015). Terapi Murottal (Al-Qur'an) Mampu Menurunkan Tingkat Kecemasan Pada Pasien Pre Operasi Laparatomi. Keperawatn Stikes Muhammadiyah Lamongan. Volume 6. Nomer 1(2015). Http://Ejournal.Umm.Ac.Id/Index.Php/K eperawatan/Article/View/2854/3507.

Binarti, Dwi., Agus Suhardi. (2014). Hubungan Antara Dukungan Keluarga Dengan Tingkat Kecemasan Pada Pasien Pre Operasi Appendictomy Di Rsud Prof. Dr. Soekandar Mojosari Kabupaten Mojokerto. Vol 11, No 2, (2014). Http://Ejournal.Stikes-

Ppni.Ac.Id/Index.Php/Jks/Article/View/1 $\underline{62 .}$

Sitepu, Sabarina \& Marataon Nasution (2015). Hubungan Dukungan Keluarga Dengan Tingkat Kecemasan Pasien Pre Operasi Di Rumah Sakit Umum Haji Medan Tahun 2015. Jurnal Volume 08 Januari 2016. 